found in erythrocytes. Thus it is doubtful whether the new name 'choleglobin' is necessary and suitable. The choice of rather unsystematic names in bile pigment nomenclature is, we find, a hindrance rather than a help to discussion.

Some other details in the letter of Lemberg and co-workers may be discussed elsewhere.

Institut de Physiologie, GEORg Barkan.

Université de Lausanne.

Universitetets Biokemiske Institut,

OtTo Schales.

Kobenhavn.

Sept. 20.

'Barkan, G., Klin. Wrchr., 1050 (1932).

2 Barkan, G., Hoppe-Seylers Z. physiol. Chem., 148, 124 (1925).

${ }^{3}$ Barkan, G., and Schales, O., Hoppe-Seylers Z. physiol. Chem., 248, 96 (1937).

- Barkan, G., and Berger, E., Klin.W Wchr., 1868 (1928) and Arch. exp. Path. u. Pharmakol., 136, 278 (1928).

"Lemberg, R., "Perspectives in Biochemistry" 137 (Cambridge University Press, 1937).

- Barkan, G., and Schales, O., Hoppe-Seylers Z. physiol. Chem., 253 83 (1938).

\section{A Viable Homozygous Deficiency in Drosophila melanogaster}

Througr combination of fragments of chromosomes from two complicated rearrangements (obtained in my work dealing with the $w^{m t}$ position effect, 1938, in the press), one of which causes a light $w^{m t}$ and the other a very dark $w^{m t}$ eye colour, the first having the break to the left and the other to the right of the $w$ gene, a stock was obtained which had no $w$ gene in its genotype. Since the cytological observations show that the breaks occur near each other, or even at the same point in both the original aberrations, it was concluded that only one gene, namely, the gene white, was deficient. The cytological data agree well with the phenotypical actions of the $w$ deficiency, which does not differ from a simple $w$ mutation, causing the white eye colour. The cytological observations agree also with the data obtained by numerous authors showing the position of the $w$ gene in the $3 C_{2}$ region of Bridges' salivary chromosome map. But in the $w$ deficiency combinations the $3 C_{2}$ band is not thinner than in the normal chromosome.

This may serve as evidence for the conception that the genes are really localized in the intrabandular a: eas. In this case the $w$ gene must be included between the disks $3 C_{2}$ and $3 C_{3}$ in the $X$-chromosome map. It may be also that this finding, which does not agree with the data of Shultz (1938), who has shown that in the $w$ mutations the $3 C_{2}$ disk is thinner than in the normal chromosome, is caused by the fact that in both of the original aberrations and in their compound, the $3 C_{1}$ and $3 C_{2}$ disks, which are translocated from chromosome IV to chromosome II $\mathrm{L}$, stain more deeply by aceto-carmine, that is, more nucleic acid is present.

The $w$ deficiency males and females (the latter have been obtained by crossing $w$-deficient males to notch $^{8}$ females) do not differ from the typical $w^{w}$ mutations, and have no other pleiotropic effects. The increased sterility of the $w$-deficient males is due probably to the original sterility effect present in one of the aberrations involved.

It is the second undoubted case of viable homozygous deficiency; the first was obtained by $\mathrm{H}$. J. Muller (1935, the $y, a c$ deficiency). The phenotypical effect which is caused by the $w$ deficiency corresponds well with Muller's theory (1932) of the action of hypomorphic and amorphic mutations. Thus, the $w$ mutations are typical amorphic mutations and probably some of them are caused by real deficiencies. The viability of the deficiencies and the absence of pleiotropic effects in these flies shows a high degree of discontinuity of the hereditary substance in the sense that the role taken by some genes is very low and that they affect few physiological functions of the whole organism. This may be caused by a high degree of duplication of genes, partially not homologous with each other.

Institute of Experimental Biology,

\section{B. Panshin.} Moscow

\section{Therinal Conductivity of Mud Brick}

INVESTIGATIONS of the thermal conductivity of mud brick, of which the methods of manufacture with mud and straw seem to have remained practically unchanged through thousands of years, have been made with small- and large-scale apparatus.

Results with small samples $10 \mathrm{~cm}$. in diameter and from $1 \mathrm{~cm}$. to $2 \mathrm{~cm}$. thick have given results ranging from $3.8 \times 10^{-4}$ calories per sq. cm. per $1^{\circ} \mathrm{C}$. temperature gradient per sec. with much straw to $8.0 \times 10^{-4}$ c.G.S. units with minimum straw.

The results with mud brick walls built vertically in $150 \mathrm{~cm} . \times 140 \mathrm{~cm} . \times 28 \mathrm{~cm}$. frames vary from $3.9 \times 10^{-4}$ to $6.0 \times 10^{-4}$ c.G.s. units. The weight of water in the bricks was found to vary by some 15 per cent according to the humidity of the air. Such bricks appear considerably better heat insulators than ordinary burnt bricks now used in constructional work, but are less heat insulating than the best cellular concrete.

\section{K. NaHas.}

F. H. Constable.

Heat Transmission Research Laboratory, Faculty of Engineering, Giza.

\section{Bluffing by Eclipse Prediction}

Lrvy's description of the Roman general, C. Sulpitius Gallus, warning his men before the battle of Pydna (168 B.c.), that an eclipse of the moon would take place on the following night is well known. He gave a scientific explanation of the phenomenon so that they should not take it as an adverse omen. The Macedonians, on the other hand, were, according to the historian, unprepared and thoroughly alarmed.

Less familiar is the very effective use of a solar eclipse by the Byzantine Emperor, Alexius I.Comnenus, who figures so prominently in the history of the First Crusade. To quote the words of his biographer, his daughter Anna Comnena :

"In the course of the discussion a certain Nicolas, one of the Emperor's secretaries, came up to him and whispered in his ear, 'You may expect an eclipse of the sun to take place to-day', and on the Emperor's expressing a doubt, he swore with an oath that he was not lying. Then the Emperor, with his habitual quick-wittedness, turned to the Scythians and said, 'I appoint God as Judge; and if a sign appears in the heavens this day, you will know for a surety that I have good reason for suspecting, and therefore not receiving, your embassy because your leaders are not sincere in their overtures for peace. If, however, 